\title{
MODEL PEMBELAJARAN ARIAS DENGAN LABORATORIUM MINI DALAM MENINGKATKAN MOTIVASI BELAJAR MATEMATIKA SISWA KELAS X SMA
}

\author{
R.A Endan Ratnawati \\ SMA Negeri 1 Pasir Penyu, Jl. Simp. Tiga Lirik Air Molek, Tanah Merah Indragiri Hulu, Riau \\ Email penulis pertama: endanzikri@gmail.com
}

\begin{abstract}
This research is motivated by the lack of students' understanding of the learning materials presented by the math teacher as the teacher of the field of study. Learning method given during this time felt less maximal to get the result of maximal learning achievement. Therefore it is deemed necessary to apply a new learning model that will increase the interest and motivation of the students in learning, especially on the subject of Mathematics. The purpose of this study is to improve the existing learning process in SMA Negeri 1 Air Molek, as well as improve the motivation to learn mathematics and improve student learning outcomes class X IPA 2 SMA Negeri 1 Pasir Penyu Lessons 2016/2017 year by looking at 5 indicators of learning model ARIAS, namely: (1) Student persistence; (2) Student self-confidence; (3) Competing soul and competition; (4) Student interest; and (5) desire to learn. The research was conducted at SMAN 1 Pasir Penyu at second grade of IPA 2 students, amounting to 32 people from August to November of the academic year 2016/2017. The study was conducted in 2 cycles where each cycle consists of stages (1) planning; (2) action; (3) observation; and (4) reflection. The results of this study illustrate that the application of ARIAS Learning Model by Mini Laboratory can improve teacher's performance of the IPA 2 semesters 1 (one) SMAN 1 Air Molek on material KD. 3.6 About Dimension Three. This can be illustrated by the percentage increase in students' motivation X-2 SMA Negeri 1 Pasir Penyu with a level of confidence of $99 \%$. This is illustrated in each indicator that the learning motivation at the time before and after the implementation of this learning model. It can be concluded that this learning model is very relevant and helps to improve students' learning motivation. Therefore, it is expected that all schools, the teachers of the learning methods are welcome.
\end{abstract}

Keywords: ARIAS Learning Model, Mini Laboratory, Student Motivation

\begin{abstract}
Abstrak
Penelitian ini dilatarbelakangi oleh rendahnya motivasi belajar siswa yang disebabkan oleh kurangnya pemahaman siswa terhadap materi pembelajaran yang disampaikan oleh guru matematika selaku guru bidang studi. Metode pembelajaran yang diberikan selama ini dirasa kurang maksimal untuk memperoleh hasil pencapaian belajar yang maksimal. Oleh karenanya dirasa perlu menerapkan suatu model pembelajaran baru yang akan meningkatkan minat dan motivasi siswa dalam belajar khususnya pada mata pelajaran Matematika. Tujuan penelitian ini adalah untuk memperbaiki proses pembelajaran yang ada di SMA Negeri 1 Air Molek, serta meningkatkan motivasi belajar matematika serta meningkatkan hasil belajar siswa kelas X IPA 2 SMA Negeri 1 Pasir Penyu Tahun Pelajaran 2016/2017 dengan melihat dari 5 indikator model pembelajara ARIAS, yaitu: (1) Keuletan siswa; (2) Kepercayaan diri siswa; (3) Jiwa bersaing dan kompetisi; (4) Minat siswa; dan (5) Keinginan belajar. Penelitian dilakukan di SMAN 1 Pasir Penyu pada siswa kelas X IPA 2 yang berjumlah 32 orang dari Bulan Agustus sampai November tahun pelajaran 2016/2017. Penelitian dilakukan dalam 2 siklus dimana setiap siklus terdiri dari tahapan (1) perencanaan; (2) tindakan; (3) observasi; dan (4) refleksi. Hasil penelitian menggambarkan bahwa penerapan Model Pembelajaran ARIAS dengan Laboratorium Mini dapat memperbaiki kinerja guru dalam proses pembelajaran dan meningkatkan motivasi belajar matematika siswa kelas X IPA 2 semester 1 (satu) SMAN 1 Air Molek pada materi KD.3.6 Tentang Dimensi Tiga. Hal ini dapat tergambarkan oleh persentase peningkatan motivasi siswa kelas X-2 SMA Negeri 1 Pasir Penyu dengan taraf kepercayaan sebesar 99\%. Hal ini digambarkan pada masing-masing indikator yang menunjukkan adanya peningkatan pada motivasi belajar siswa pada saat sebelum dan setelah diterapkannya model pembelajaran ini. Dapat disimpulkan bahwa model pembelajaran ini sangat relevan dan membantu untuk meningkatkan motivasi belajar siswa. Maka dari itu diharapkan kepada seluruh pihak sekolah, baik guru bidang studi maupun kepala
\end{abstract}


sekolah dapat menjadikan metode pembelajaran langsung ini menjadi salah satu metode pembelajaran yang diterapkan di sekolah, dan kepada seluruh siswa diharapkan dapat belajar lebih kooperatif lagi tehadap materi pembelajaran yang disampaikan oleh guru.

Kata Kunci: Model Pembelajaran ARIAS, Laboratorium Mini, Motivasi Belajar Siswa

Peningkatan mutu pendidikan merupakan usaha yang terus dilakukan pemerintah. Usaha ini bertujuan untuk meningkatkan kualitas Sumber Daya Manusia (SDM) guna mengimbangi kemajuan Ilmu Pengetahuan dan Teknologi (IPTEK). Matematika merupakan salah satu penunjang IPTEK dari segala ilmu dan juga sebagai bahasa dari berbagai ilmu pengetahuan. Dengan belajar matematika diharapkan siswa akan memiliki kemampuan berfikir logis, sistematis, kritis, kreatif serta sifat bekerjasama. Dalam proses pembelajaran matematika guru berupaya mendidik dan melatih siswa dalam belajar agar bertujuan pembelajaran matematika disekolah dapat tercapai dengan optimal.

Menurut tim Depdiknas (2003) bahwa tujuan pembelajaran matematika pada kurikulum Matematika 2003 adalah :

1. Melatih cara berfikir dan bernalar dalam menarik kesimpulan, misalnya melalui kegiatan penyelidikan, eksplorasi, eksperimen.

2. Mengembangkan aktivitas kreatif yang melibatkan imajinasi, intuisi, dan penemuan dengan mengembangkan pemikiran divergen, orosinil, rasa ingin tahu, membuat prediksi dan dugaan, serta mencoba-coba.

3. Mengembangkan kemampuan pemecahan masalah.

4. Mengembangkan kemampuan menyampaikan informasi atau mengkomunikasikan gagasan antara lain melalui pembicaraan lisan, catatan, grafik, diagram, dan menjelaskan gagasan.

Matematika sebagai salah satu ilmu dasar mempunyai peranan penting dalam upaya penguasaan ilmu dan teknologi. Matematika diperkenalkan pada siswa guna menumbuh kembangkan kemampuan-kemampuan dan membentuk peribadi siswa kepada ilmu dan teknologi. Kemampuan ini memerlukan pemikiran yang kritis, logis, sistematis, kreatif dan kemampuan bekerja sama yang efektif.

Badan Standar Nasional Pendidikan (2006: 2) yang menyebutkan bahwa:

"Tujuan pembelajaran matematika agar peserta didik memiliki kemampuan: (1) memahami konsep matematika, menjelaskan keterkaitan antara konsep dan pengaplikasian konsep dan algoritma secara luwes, akurat, efesien dan tepat dalam pemecahan masalah; (2) menggunakan penalaran pada pola dan sifat, melakukan manipulasi matematika dalam membuat generalisasi, menyusun bukti, atau menjelaskan gagasan dan pernyataan matematika; (3) memecahkan masalah yang meliputi kemampuan memahami masalah, merancang model matematika, menyelesaikan model dan menafsirkan solusi yang diperoleh; (4) mengkomunikasikan gagasan dengan simbol, tabel, diagram, atau media lain untuk memperjelas keadaan masalah; (5) memiliki sikap menghargai kegunaan matematika dalam kehidupan, yaitu rasa ingin tahu, perhatian dan minat dalam mempelajari matematika, serta sikap ulet dan percaya diri dalam pemecahan masalah."

Cara berfikir yang kritis, logis, sistematis, kreatif dan kemampuan bekerja sama yang efektif dapat dikembangkan melalui belajar matematika. Selanjutnya Suharsimi Arikunto (2010: 145) menyatakan bahwa "tujuan pengajaran atau instruksional pendidikan adalah tujuan yang menggambarkan pengetahuan, kemampuan, keterampilan dan sikap yang harus dimiliki oleh siswa sebagai akibat dari hasil pengajaran yang dinyatakan dalam bentuk tingkah laku yang dapat diamati dan diukur." 
Palardi (dalam Imran, 1996) menyatakan motivasi belajar memegang peranan penting dalam memberikan gairah, semangat dan rasa senang dalam belajar, sehingga akan mempunyai energi yang banyak untuk melakukan kegiatan belajar.

Apabila siswa telah mempunyai keinginan untuk berbuat sesuatu atau telah termotivasi untuk belajar, maka siswa tersebut akan mempersiapkan diri lebih awal untuk belajar. Selanjutnya guru matematika hendaknya selalu memberikan motivasi pada siswa untuk meningkatkan kegiatan belajar siswa dengan menyatakan kegunaan atau menyampaikan tujuan pembelajaran dari setiap materi yang diajarkan, menciptakan suasana pembelajaran yang melibatkan siswa aktif dalam belajar, kreatif dan manarik.

Berdasarkan pengamatan dan wawancara penulis dengan guru SMA Negeri 1 Pasir Penyu Kabupaten Indragiri Hulu tentang motivasi belajar matematika siswa tergolong rendah, khususnya kelas X-2 tahun pelajaran 2017/2018. Dalam proses pembelajaran siswa cenderung pasif atau tidak ikut berpartisipasi dalam pembelajaran.

Sebagian besar siswa menganggap bahwa pelajaran matematika sebagai pelajaran yang sulit dan menakutkan. Terlebih lagi pelajaran matematika dengan guru yang "killer" dan menyeramkan akan menambah semakin tidak menentunya konsentrasi belajar siswa. Hal ini berakibat kepada siswa yang akan sulit dalam memahami materi pelajaran yang dipelajarinya. Siswa merasa takut jika diberi soal atau pertanyaan, bahkan siwa merasa takut dengan guru, ketika guru masuk ke dalam kelas.

Sebagian siswa tidak memperhatikan pada saat guru menerangkan materi di depan kelas, siswa tidak bersemangat mengerjakan latihan yang diberikan guru dan hanya menunggu dari teman-teman, siswa menganggap dirinya tidak pintar dalam pelajaran matematika dan tidak yakin kalau mereka dapat belajar matematika dengan baik. Siswa juga sering mengeluh kesulitan dalam memahami unit geometri, diantaranya siswa sering kebingungan menentukan panjang, lebar atau tinggi sebuah bangun datar yang gambarnya berbeda dengan gambar yang dibuat guru.

Upaya dalam meningkatkan motivasi belajar matematika telah dilakukan guru matematika, seperti memberi semangat kepada siswa untuk belajar, memberi penghargaan terhadap prestasi yang dicapai siswa sehingga berkeinginan untuk mendapatkan prestasi yang lebih baik, dan bagi siswa yang telah memperoleh penghargaan maka mereka termotivasi ingin belajar lebih baik, membantu kesulitan siswa secara individu. Usaha-usaha yang mengarah untuk meningkatkan motivasi telah dilakukan namun motivasi belajar matematika siswa kelas X-2 SMA Negeri 1 Pasir Penyu Kabupaten Indragiri Hulu masih rendah.

Masalah-masalah diatas perlu diantisipasi dengan mencari dan menerapkan model pembelajaran yang tepat sehingga dapat meningkatkan motivasi belajar matematika siswa. Untuk itu penulis mencoba untuk melakukan penelitian tentang Model Pembelajaran ARIAS Dengan Laboratorium Mini sehingga dapat meningkatkan motivasi siswa dalam belajar matematika terutama dalam materi pokok Dimensi Tiga salah satu materi geometri yang dianggap sulit oleh siswa.

Model Pembelajaran ARIAS merupakan modifikasi dari ARCS yang dikembangkan oleh Keller dan Krop. Model pembelajaran ini dikembangkan berdasarkan teori nilai harapan (expectancy value theory) yang mengandung dua komponen yaitu: nilai (value) dan tujuan yang akan dicapai dan harapan (expectancy) agar berhasil mencapai tujuan itu. Dari dua komponen tersebut oleh Keller dikembangkan menjadi empat komponen yaitu: Attention (minat/perhatian), Relevance (relavansi), Confidence (percaya/yakin), Satisfacion (kepuasan/bangga). Pada model pembelajaran ini tidak ada evaluasi (Assessment), padahal evaluasi merupakan komponen yang tidak dapat dipisahkan dalam 
kegiatan pembelajaran. Mengingat pentingnya evaluasi, maka model pembelajaran ini dimodifikasi dengan menambahkan komponen evaluasi, sehingga menjadi Model Pembelajaran ARIAS (Assurance/percaya diri, Relevance/relavansi, Interest/minat, Assessment/evaluasi, dan Satisfaction/rasa puas), (Sopah, 1998).

Makna dari modifikasi ini adalah usaha pertama dalam kegiatan pembelajaran untuk menanamkan rasa yakin/percaya diri pada siswa. Kegiatan pembelajaran ada relavansinya dengan kehidupan siswa, berusaha menarik perhatian dan memelihara minat/perhatian siswa. Kemudian diadakan evaluasi dan menumbuhkan rasa bangga pada siswa dengan memberikan penguatan (reinforcement).Agar siswa tidak merasa bosan, guru harus bisa melibatkan siswa selama proses pembelajaran dan menyajikan relavansi materi dengan kehidupan siswa. Salah satunya dengan bantuan Laboratorium Mini yang diharapkan dapat menarik minat siswa sekaligus melibatkan siswa secara aktif.

Kegiatan Laboratorium Mini dapat membantu siswa memahami konsep-konsep matematika yang bersifat abstrak. Soedjana (1986) mengatakan dengan kegiatan Laboratorium Mini siswa dapat menggunakan benda-benda konkret dan mengotak-atiknya (memanipulasi) untuk memahami, memerikas, meneliti, menyimpulkan, mengaplikasikan atau mendapat suatu objek langsung matematika.

Berbagai usaha dapat dilakukan dalam model pembelajaran ARIAS untuk menumbuhkan rasa percaya diri siswa, menarik minat siswa dan mempertahankannya selama proses pembelajaran, memberikan gambaran tentang manfaat belajar matematika kepada siswa dan memberikan rasa senang kepada siswa dalam belajar matematika. Agar siswa lebih tertarik dan berminat untuk mempelajari matematika serta mengatasi rasa bosan siswa terhadap pembelajaran matematika, penulis menggabungkan model pembelajaran ARIAS dengan Laboratorium Mini, karena dengan laboratorium mini siswa dapat ikut aktif dalam proses pembelajaran. Sehingga dengan menggabungkan model pembelajaran ARIAS dengan laboratorium mini dapat meningkatkan motivasi belajar matematika siswa.

\section{METODE}

Jenis penelitian ini adalah Penelitian Tindakan Kelas (PTK) yang terdiri dari 2 siklus, yang setiap siklusnya memiliki tahapan yakni: (1) tahapan perencanaan, (2) tahapan perencanaan, (3) tahapan obervasi dan (4) tahapan refleksi. Sukayanti (2001) menyatakan penelitian tindakan kelas adalah suatu penelitian yang bertujuan untuk memperbaiki kekurangan-kekurangan dalam pembelajaran kelas dengan cara melakukan tindakan-tindakan tertentu agar dapat memperbaiki dan meningkatkan praktek-praktek pembelajaran dikelas. Wardani (2002) menyatakan penelitian tindakan kelas adalah merupakan penelitian yang dilakukan oleh guru didalam kelasnya sendiri melalui refleksi diri dengan tujuan memperbaiki kinerjanya sebagai guru sehingga motivasi belajar siswa meningkat.

Dalam penelitian ini, peneliti dan guru berkolaboratif dalam merencanakan tindakan dan refleksi hasil tindakan sehingga bentuk penelitian ini tergolong kepada penelitian kolaboratif. Pelaksanaan tindakan oleh peneliti dan guru sebagai pengamat selama proses pembelajaran. Tindakan dalam penelitian ini adalah penerapan Model Pembelajaran ARIAS Dengan bantuan Laboratorium Mini dalam pembelajaran matematika pada materi pokok kesebangunan untuk meningkatkan motivasi belajar siswa kelas X-2 SMA Negeri 1 Pasir Penyu Kabupaten Indragiri Hulu.

Wardana (2002) menyatakan Penelitian tindakan kelas adalah penelitian yang dilakukan oleh guru di dalam kelas melalui refleksi diri dengan tujuan memperbaiki kinerjanya sebagai guru, 
sehingga motivasi belajar siswa menjadi meningkat. Adapun daur siklus penelitian tindakan kelas menurut Wardani (2002) yaitu sebagai berikut :

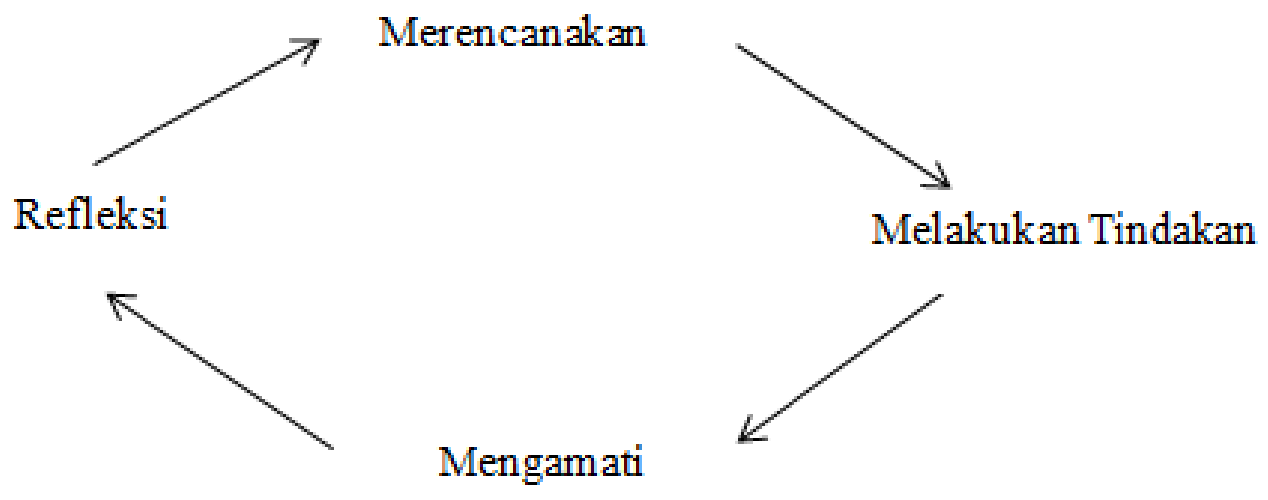

Gambar 1. Daur Siklus Penelitian Tindakan Kelas

1. Merencanakan: rencana tindakan kelas "apa" yang dilakukan untuk memperbaiki, meningkatkan/perubahan prilaku dan sikap sebagai solusi.

2. Melakukan Tindakan: apa yang dilakukan oleh guru atau peneliti sebagai upaya perbaikan, peningkatan atau perubahan yang diinginkan.

3. Mengamati: mengamati atas hasil atau dampak dari tindakan yang dilaksanakan atau dikenakan terhadap siswa.

4. Refleksi: peneliti mengkaji, melihat dan mempertimbangkan atas hasil atau dampak dari tindakan diberbagai kriteria.

Peneliti melakukan dua siklus, masing-masing komponen pada setiap siklus dalam penelitian ini berisikan :

1. Merencanakan: menyusun Skenario Pembelajaran, Lembar Kerja Siswa, mempersiapkan soal evaluasi dan mempersiapkan Lembar Pengamatan.

2. Melakukan Tindakan: memotivasi siswa dalam melakukanModel Pembelajaran ARIAS Dengan bantuan Laboratorium Mini.

3. Melakukan Observasi: observasi dilakukan bersamaan dengan pelaksanaan tindakan, pelaksanaan observasi dilakukan oleh peneliti dan guru yang melaksanakan tindakan dan menggunakan lembar pengamatan.

4. Refleksi: mengkaji, melihat dan mempertimbangkan atas hasil atau dampak dari tindakan. Kelemahan dan kekurangan dari tindakan diperbaiki pada rencana selanjutnya.

Penelitian ini dilaksanakan di SMA Negeri 1 Pasir Penyu Kabupaten Indragiri Hulu. Sedangkan waktu penelitian dilaksanakan selama 4 bulan yang dimulai dari bulan Agustus sampai dengan November 2017. Penelitian ini dilakukan di SMA Negeri 1 Pasir Penyu Kabupaten Indragiri Hulu tahun pelajaran 2017/2018. Sebagai subjek penelitian ini adalah siswa kelas X-2 SMA Negeri 1 Pasir Penyu Kabupaten Indragiri Hulu sebanyak 32 siswa. Kemampuan akademik siswa dikelas X-2 SMA Negeri 1 Pasir Penyu Kabupaten Indragiri Hulu ini dikategorikan sedang dan berprilaku pasif dalam belajar. 


\section{Instrumen Penelitian}

1. Perangkat Pembelajaran

Perangkat pembelajaran yang diperlukan dalam penelitian ini adalah Silabus, Skenario Pembelajaran dan Lembar Kerja Siswa (LKS). Skenario Pembelajaran disusun dengan memperhatikan langkah-langkah pada penerapan Model Pembelajaran ARIAS Dengan bantuan Laboratorium Mini. Skenario Pembelajaran yang akan digunakan menurut standar kompetensi, kompetensi dasar, indikator, model dan metode pembelajaran, kegiatan pembelajaran yang memuat kegiatan awal, kegiatan inti dan kegiatan akhir. Lembar kerja siswa yang digunakan memuat indikator, langkah-langkah kerja dan konsep matematika yang harus ditemukan. LKS ini disusun sesuai dengan Model Pembelajaran ARIAS Dengan bantuan Laboratorium Mini sehingga berfungsi untuk meningkatkan motivasi belajar matematika siswa dalam proses pembelajaran.

2. Instrumen Pengumpulan Data

Data yang dikumpulkan pada penelitian ini adalah tentang skor motivasi belajar siswa sebelum pembelajaran dan sesudah mengikuti model pembelajaran yang diterapkan. Data tersebut dikumpulkan dengan menggunakan angket. Instrumen ini disusun berdasarkan indikator-indikator motivasi belajar matematika siswa yang telah ditetapkan pada uraian sebelumnya. Adapun indikator yang dimaksud adalah :

a) Ulet menghadapi kesulitan

b) Percaya diri

c) Bersaing / kompetisi

d) Minat terhadap persoalan matematika

e) Keinginan untuk belajar.

Kemudian dari indikator-indikator tersebut disusun pernyataan-pernyataan yang dikategorikan atas dua jenis yakni pernyataan yang bersifat positif dan pernyataan bersifat negatif (Sukardi, 2003).

Teknik pemberian skor terhadap jawaban yang diberikan siswa terhadap pernyataanpernyataan yang diajukan digunakan skala Likert sebagai berikut :

a) Untuk pernyataan yang bersifat positif skor ditetapkan sebagai berikut :

1) Skor 4 untuk jawaban Sangat Setuju (SS).

2) Skor 3 untuk jawaban Setuju (S).

3) Skor 2 untuk jawaban Tidak Setuju (TS).

4) Skor 1 untuk jawaban Sangat Tidak Setuju (STS).

b) Untuk pernyataan yang bersifatnegatif skor ditetapkan sebagai berikut :

1) Skor 4 untuk jawaban Sangat Tidak Setuju (STS).

2) Skor 3 untuk jawaban Tidak Setuju (TS).

3) Skor 2 untuk jawaban Setuju (S).

4) Skor 1 untuk jawaban Sangat Setuju (SS).

Adapun sebaran butir pernyataan angket untuk setiap indikator dan jenis pernyataan yang dapat dilihat pada tabel berikut : 
Tabel 1. Indikator dan Sebaran Jenis Butir Pernyataan Angket

\begin{tabular}{ccccc}
\hline No. & Indikator & \multicolumn{2}{l}{ No. Pernyataan } & Jumlah Pernyataan \\
\hline 1 & $\begin{array}{c}\text { Ulet menghadapi } \\
\text { kesulitan }\end{array}$ & 1.2 & 3.4 & 4 \\
2 & Percaya diri & 5.6 & 7.8 & 4 \\
3 & $\begin{array}{c}\text { Bersaing / } \\
\text { kompetisi }\end{array}$ & 9.10 & 11.12 & 4 \\
& $\begin{array}{l}\text { Minat dan } \\
\text { konsentrasi } \\
\text { terhadap } \\
\text { permasalah } \\
\text { matematika }\end{array}$ & 13.14 & 15.16 & 4 \\
& & & 4 \\
& Keinginan untuk \\
belajar & 17.18 & 19.20 & 4 \\
\hline
\end{tabular}

\section{Teknik Mengumpulkan Data}

Untuk mengumpulkan data tentang motivasi siswa terhadap matematika dalam pembelajaran dengan pembelajaran Model Pembelajaran ARIAS Dengan bantuan Laboratorium Mini adalah :

1) Memberikan angket motivasi kepada siswa sebelum pemberian tindakan.

2) Melakukan pengamatan terhadap aktifitas guru dan siswa saat berlangsungnya proses pembelajaran.

3) Memberikan angket motivasi kepada siswa sesudah pemberian tindakan.

Angket yang diisi siswa dikumpulkan langsung, ini bertujuan agar hasil angket tidak terlalu jauh dipengaruhi oleh faktor-faktor lain. Hal ini dimaksudakan agar skor angket yang diperoleh siswa menunjukkan motivasi belajar matematika siswa yang benar-benar sebagai akibat dari penerapan tindakan pembelajaran yang diterapkan.

\section{Teknik Analisis Data}

Data skor motivasi belajar siswa terhadap matematika yang diperoleh diolah dengan menggunakan Uji Tanda, untuk melihat apakah tanda terdapat peningkatan motivasi belajar siswa setelah diterapkan Model Pembelajaran ARIAS Dengan bantuan Laboratorium Min. Adapun langkahlangkah yang digunakan sebagai berikut :

1) Merumuskan hipotesis

$$
\text { Ho : p }(\text { X2 }>\text { XI })=\mathbf{p}(\mathbf{X} 2<\mathrm{XI})
$$

Artinya:

Peluang meningkatnya motivasi belajar sama dengan peluang menurunnya motivasi belajar.

$$
\text { HI : p }(\mathrm{X} 2>\mathrm{XI})=\mathbf{p}(\mathrm{X} 2<\mathrm{XI})
$$


Artinya:

Peluang meningkatnya motivasi belajar lebih besar dan peluang menurunnya motivasi belajar.

2) Menetapkan $\square=0,01$

3) Uji statistik yang digunakan adalah uji tanda dengan rumus :

$x=\frac{(X \pm 0,5)-\frac{1}{2} N}{\frac{1}{2} \sqrt{N}}$

Keterangan :

$\mathrm{X}=$ jumlah tanda positif

$\mathrm{X}_{\mathrm{I}}=$ skor motivasi sebelum tindakan

$\mathrm{X}_{2}=$ skor motivasi sesudah tindakan

$\mathrm{N}=$ jumlah tanda positif dan negatif

$X+0,5 ;$ jika $X \leq 1 / 2 N$ dan $X-0,5 ;$ jika $X>1 / 2 N$

Dengan kriteria pengujian hipotesis (Ho) sebagai berikut:

"tolak $\mathrm{H}_{0}$ jika $\mathrm{p}<\alpha$, terima $\mathrm{H}_{0} \mathrm{p} \geq \alpha$. Nilai $\mathrm{p}$ diperoleh dan distribusi normal."

\section{HASIL DAN PEMBAHASAN}

\section{Siklus Pertama}

a) Pertemuan Pertama

Pelaksanaan pembelajaran sesuai RPP-01tentang Kedudukan Titik, Garis, Atau Bidang Pada Bangun Ruang . Pada kegiatan awal penulismemperkenalkan diri, menyebarkan angket motivasi belajar, menyampaikanmodel pembelajaran yang akan digunakan dan menyampaikan kompetensi yang harus dicapai siswa.

Penulis secara singkat menjelaskan materi pelajaran dan mendemonstrasikan tentang Kedudukan Titik, Garis, Atau Bidang Pada Bangun Ruang, sebagian siswa ada yang bermain dengan lidi atau karton mereka disaat penulis menjelaskan materi pelajaran. Setelah itu siswa diminta mengerjakan LKS-01, siswa mengerjakan apa yang diperintahkan. Disini penulis melihat siswa merasa senang dan berminat untuk mengamati kerangka bangun-bangun ruangdi kelompok mereka masing-masing, hal ini terlihat dari hampir seluruh siswa mengamati bangun-bangun ruang tersebut. Tetapi penulis tidak melihat adanya keuletan siswa dalam rnengerjakan LKS-01, dimana siswa selalu bertanya kepada teman mereka dan penulis tanpa berusaha terlebih dahulu menemukan sendiri. Selama kegiatan pembelajaran berlangsung, penulis mengamati aktifitas siswa dan memberikan penilaian hasil kerja siswa. Penulis memberikan pujian (reinforcement) kepada siswa yang memperlihatkan keberhasilannya dan memberikan dorongan motivasi kepada siswa yang terlihat malas-malasan. 
Setelah mereka selesai, penulis mengarahkan siswa untuk menemukan Hubungan Antara Titik Dan Garis, Hubungan Antara Titik dan Bidang, Hubungan Antara Garis - Garis dalam Ruang, Hubungan antara Bidang - Bidang dilanjutkan dengan Hubungan antara Garis dan Bidang. Secara umum siswa dapat mengetahui Hubungan Titik, Garis, atau Bidang Pada Bangun Ruang. Setelah itu penulis memberikan soal evaluasi yang berkaitan dengan materi tersebut. Seluruh siswa mengerjakan soal yang telah diberikan penulis, setelah dikumpul penulis membahas soal evaluasi kemudian memberikan kesempatan kepada siswa untuk menjawab soal evaluasi tersebut, disini terlihat hampir seluruh siswa mengacungkan tangan ingin menjawab sehingga suasana kelas menjadi ribut, tetapi penulis menunjuk salah satu dari siswa untuk menjawabnya. Jika jawaban siswa benar penulis memberikan reiforcement berupa pujian.

Pada kegiatan penutup sekali lagi penulis menekankan Hubungan Titik, Garis Atau Bidang Pada Bangun Ruang. Kemudian penulis memberikan soal tugas yang harusdikerjakan siswa dan meminta siswa membaca lanjutan materi berikutnya. Pada pertemuan ini terlihat aktivitas siswa yang diamati, sebagian siswa belum termotivasi secara aktif dalam proses pembelajaran dan belum sesuai dengan apa yang diharapkan tetapi untuk indikator percaya diri sudah mulai ada peningkatan.

b) Pertemuan Kedua

Pelaksanaan pembelajaran sesuai RPP- 02. Pada kegiatan awal penulis membahas soal tugas yang telah dikerjakan bersama-sama siswa, terlihat siswa bersemangat menujukan hasil yang mereka kerjakan pada penulis. Selanjutnya penulis menyampaikan kompetensi yang harus dicapai dan penulis menjelaskan materi secara singkat. Pada kegiatan inti siswa memperlihatkan keuletannya. Terlihat dari siswa yang berusaha untuk menentukankedudukan garis terhadap bidang dan kedudukan bidang terhadap bidang lain dalam ruang dimensi tiga yang dimaksud dalam LKS-02. Hanya ada beberapa siswa yang bertanya kepada penulis dan penulis meminta siswa tersebut kepada temannya yang telah berhasil. Semua siswa mengerjakan sesuai yang diperintahkan dalam LKS-02 dan hanya ada beberapa siswa yang tak berhasil dan masih ada yang menunggu teman yang berhasil. Penulis memberi pujian kepada siswa yang berhasil dengan pujian verbal dan non verbal. Siswa terlihat sangat puas karena berhasil menentukan menentukan kedudukan garis terhadap bidang dan kedudukan bidang terhadap bidang lain dalam ruang dimensi tiga dan siswa dengan semangat untuk melanjutkan perintah LKS berikutnya.

Setelah mereka selesai, penulis memberikan soal evaluasi yang berkaitan dengan cara menentukan menentukan kedudukan garis terhadap bidang dankedudukan bidang terhadap bidang lain dalam ruang dimensi tiga. Seruruh siswa mengerjakan soal yang telah diberikan penulis, selama mengerjakan soal evaluasi siswa terlihat tenang mengerjakannya meskipun ada beberapa orang siswa bertanya-tanya kepada temannya. Setelah dikumpul penulis memberikan kesempatan siswa untuk menjawab soal evaluasi, disini terlihat hampir seluruh siswa mengacungkan tangan ingin menjawab sehingga suasana kelas menjadi ribut, tetapi penulis menujuk salah satu dari siswa untuk menjawabnya. Jika jawaban siswa benar penulis memberikan reiforcement berupa pujian.

Pada kegiatan penutup penulis meminta siswa menyebutkan kesimpulan dari materi pelajaran. Selanjutnya penulis memberikan soal tugas yang harus dikerjakansiswa dirumah dan meminta siswa membaca lanjutan materi berikutnya. Padapertemuan ini terjadi peningkatan 
pada indikator percaya diri, indikator uletmenghadapi kesulitan mulai ada peningkatan begitu juga dengan indikator minat terhadap persoalan matematika.

c) Pertemuan Ketiga

Pelaksanaan pembelajaran sesuai RPP-03. Pada kegiatan awal penulis bersama siswa membahas soal tugas, penulis menyampaikan materi secara singkat dan mendemonstrasikan tahap-tahap pada LKS-03. Kemudian meminta siswa melakukan sendiri dengan alat yang telah tersedia. Selama siswa melakukan kegiatan penulis berkeliling-keliling mengarahkan mereka jika ada yang mengalami kesulitan, disini penulis melihat adanya kemajuan dari diri siswa yaitu hampir semua siswa berusaha untuk memahami cara menentukan Jarak pada bangun ruang ( jarak titik ke titik dan jarak titik ke garis). Mereka juga sudah tidak disebut lagi dan tidak lagi menunggu hasil dari temannya, disini terlihat percaya diri mereka sudah nampak.Setelah mereka selesai melakukan kegiatan dan sudah dapat menemukan cara menentukan Jarak pada bangun ruang ( jarak titik ke titik dan jarak titik ke garis). Penulis meminta siswa untuk menyebutkan kesimpulan yang mereka dapatkan, hampir seluruhnya mengacungkan tangan untuk menjawab. Kemudian penulis menujuk salah satu siswa untuk menyebutkan, kalau benar maka penulis memberikan reiforcement berupa pujian kepada siswa tersebut.

Selanjutnya penulis memberikan soal evaluasi, disini terlihat siswa sudah mulai berminat dengan persoalan matematika dimana dengan tenang merekamengerjakan soal tersebut. Setelah selesai mereka kerjakan lalu dikumpul, penulis lalu membahas soal evaluasi dan mereka mulai ribut lagi masing-masing mengacukan tangan untuk menjawab.

Pada kegiatan penutup penulis meminta siswa mengerjakan tugas di rumah dan meminta siswa membaca materi yang telah dipelajari untuk mengikuti pertemuan berikutnya. Pada pertemuan ini, selain indikator ulet menghadapi kesulitan dan indikator percaya diri ada peningkatan, untuk indikator minat terhadap persoalan matematika dan manfaat materi pelajaran matematika belum nampak jelas ada peningkatan.

Resume siklus pertama, yaitu:

1) Refleksi awal

Dalam proses pembelajaran siswa cendrung pasif atau tidak ikut berpartisipasi dalam pemberajaran. Diantaranya sebagian siswa tidak memperhatikan pada saat guru menerangkan materi di depan kelas. Siswa tidak bersemangat mengerjakan latihan yang diberikan guru dan hanya menunggu dari teman-teman, sebagian siswa menganggap dirinya tidak pintar dalam pelajaran matematika dan tidak yakin kalau mereka dapat belajar matematika dengan baik. Siswa juga sering mengeluh kesulitan dalam memahami unit geometri, diantaranya siswa sering kebingungan menentukan bidang atau garis pada bangun ruang yang gambarnya berbeda dengan gambar yang dibuat guru.

2) Perencanaan

Pada siklus pertama ini dilaksanakan tiga kali pertemuan dan satu kali test dengan menggunakan Model pembelajaran ARIAS dengan Laboratorium Mini sesuai dengan skenario pembelajaran untuk meningkatkan motivasi belajar matematika siswa.

3) Tindakan yaitu melakukan tindakan sesuai dengan perencanaan.

4) Observasi

(a) Pada pertemuan pertama penulis melihat belum ada keuletan siswa dalam mengerjakan LKS, ini terlihat siswa selalu bertanya tanpa berusaha terlebih dahulu menemukan sendiri. Di saat penulis membahas soal evaluasi, hampir seluruh siswa 
ingin menjawab sehingga suasana kelas jadi ribut. Di sini terlihat percaya diri siswa mulai terlihat ada peningkatan.

(b) Pada pertemuan kedua penulis mulai melihat ada peningkatan keuletansiswa dalam mengerjakan LKS, ini terlihat sebagian siswa mulai berusaha sendiri tapi ada beberapa siswa yang masih bertanya kepada penulis.

(c) Pertemuan ketiga, dari empat indikator yang terlihat ada peningkatan hanya pada indikator ulet menghadapi kesulitan dan indikator percaya diriuntuk indikator lainnya belum terjadi peningkatan.

\section{5) Refleksi akhir}

Selama penelitian berlangsung pada siklus pertama penulis banyak mengalami kesulitan antara lain: penulis mengalami kesulitan mengarahkan agar tidak ribut mengerjakan LKS; pengamat mengatakan bahwa penulis kurang keras suaranya dalam menjelaskan materi dan langkah-langkah pada LKS; dari penulis sendiri ada kekurangan pada LKS, dimana pada LKS penulis tidak adamemerintahkan kepada siswa membuat gambar bangun-bangun datar sesuai keinginan siswa sendiri sehingga contoh gambar pada LKS saja yang mereka lakukan; dalam mengerjakan soal evaluasi tidak sesuai dengan waktu yang penulis tentukan. Selain ada kekurangan juga ada kelebihan disini siswa terlihat senangdalam mengerjakan apa yang diperintahkan pada LKS dan siswa juga lebih aktif bertanya jika mengalami kesulitan. Dari empat indikator yang mulai terlihat pada siklus pertama yaitu: indikator ulet menghadapi kesulitan dan percaya diri sedang indikator minat terhadap persoalan matematika dan manfaat materi pelajaran matematika belum ada peningkatan.

\section{Siklus Kedua}

a) Pertemuan Keempat

Pelaksanaan sesuai dengan RPP-04 tentang Jarak titik keBidangJarak Pada Bangun Ruang. Pada kegiatan awal penulis bersama siswa membahas tugas yang telah mereka kerjakan di rumah dan menyampaikan kompetensi yang harus dicapai siswa. Penulis menanyakan kembali tentang Kedudukan Titik, Garis, Atau Bidang Pada Bangun Ruang sebagai materiprasyarat dan siswa dengan semangat menjawabnya bersama-sama.

Penulis menjelas secara singkat dan kemudian meminta siswa melakukan tahap-tahap pada LKS-04 tentang Jarak Pada Bangun Ruang, siswa mulai mengerjakan apa yang telah diperintahkan penulis untuk menghitung Jarak titik ke Bidang, Jarak Dua Garis Bersilangan, dilanjutkan Jarak Dua Bidang yang Sejajar. Disini terlihat siswa dengan semangat mengisi LKS-04 sesuai apa yang telah ditemukan dalam melakukan kegiatan pada tahaptahap LKS-04.

Setelah selesai melakukan kegiatan, siswa menanyakan soal evaluasi untukmereka kerjakan, siswa mulai berminat mengerjakan soal-soal evaluasi.Kemudian penulis memberikan soal evaluasi. Siswa mengerjakan soal evaluasi dengan semangat sesuai konsep yang telah mereka lakukan pada LKS-04. Setelah selesai jawaban mereka dikumpul. Kemudian penulis membahas bersama-sama terlihat siswa senang dengan jawaban mereka dan merasa bangga telah berhasil menjawab dengan benar, mereka saling bertanya-tanya kepada teman-temannya tentang hasil jawaban masing-masing.

Pada pertemuan indikator ulet menghadapi kesulitan, indikator percaya diri, untuk indikator minat terhadappersoalan matematika dan indikator manfaat materi pelajaran matematika mulaiada peningkatan. 
b) Pertemuan kelima

Pelaksanaan pembelajaran sesuai RPP-05 tentang Besar Sudut Pada Bangun Ruang ( Sudut antara dua garis dan sudut antara garis dan bidang ). Pada kegiatan awal penulis bersama siswa membahas soal tugas telihat siswa senang mendapatkan bahwa hasil kerja mereka bagus dan penulis memotivasi siswa yang kerjanya masih terdapat kesalahan, untuk belajar lebih giat lagi, dan menyampaikan kompetensi yang harus dicapai, memotivasi siswa serta menumbuhkan keyakinan pada siswa bahwa mereka dapat menemukan Besar Sudut Pada Bangun Ruang (Sudut antara dua garis dan sudut antara garis dan bidang ). Penulis menyampaikan materi secara singkat dan mendemonstrasikan tahap-tahap pada LKS-05. Kemudian meminta siswa melakukan sendiri dengan alat dan bahan yang telah tersedia. Selama siswa melakukan kegiatan penulis berkeliling-keliling mengarahkan mereka jika ada yang mengalami kesulitan, disini penulis melihat adanya kemajuan dari diri siswa yaitu hampir semua siswa berusaha mengamati bangun-bangun ruang untuk menentukan sudut pada bangun ruang. Mereka juga sudah tidak berebut lagi dan tidak lagi menunggu hasil dari temannya, disini terlihat percaya diri mereka sudah nampak.

Setelah mereka selesai melakukan kegiatan dan sudah dapat menemukan besar sudut antara dua garis pada bangun ruang kubus, penulis meminta siswa untuk mengamati rusukrusuk pada kerangka kubus, selanjutnya mengamati pasangan rusuk-rusuk kubus untuk mengamati sudut antara kedua garis, hampir seluruhnya siswa mengacungkan tangan untuk menjawab.Kemudian penulis menujuk salah satu siswa untuk menyebutkan, kalau benar maka penulis memberikan pujian kepada siswa tersebut.

Selanjutnya penulis memberikan soal latihan, disini terlihat siswa sudah mulai berminat dengan persoalan matematika dimana dengan tenang mereka mengerjakan soal tersebut. Setelah selesai mereka kerjakan lalu dikumpul, penulis lalu membahas soal evaluasi dan mereka mulai ribut lagi masing-masing mengacukan tangan untuk menjawab.

Pada penutup penulis memberikan soal tugas yang dikerjakan di rumahdan meminta siswa membaca materi selanjutnya. Padapertemuan indikator ulet menghadapi kesulitan, indikator percaya diri, untuk indikator minat terhadap persoalan matematika dan indikator manfaat materi pelajaran matematika mulaiada peningkatan.

c) Pertemuan Keenam

Pelaksanaan sesuai dengan RPP-06 tentang Besar Sudut Pada Bangun Ruang ( Sudut antara dua bidang ). Pada kegiatan awal penulis bersama siswa membahas tugas yang telah mereka kerjakan di rumah dan menyampaikan kompetensi yang harus dicapai siswa. Penulis menanyakan kembali syarat-syarat menggambar bangun ruang dan siswa dengan semangat menjawabnya bersama-sama.

Penulis menjelas secara singkat dan kemudian meminta siswa melakukantahap-tahap pada LKS-06 dengan menggunakan kerangka bangun ruang yang ada pada kelompok masing masing untuk menentukan letak sudut antara dua bidang dilanjutkan dengan menghitung besar sudut antara dua bidang. Disini terlihat siswa dengan semangat mengisi LKS-06 mereka sesuai apa yang telah ditemukan dalam melakukan kegiatan pada tahap-tahap LKS-06.

Setelah selesai melakukan kegiatan, siswa mengerjakan soal latihan untuk mereka kerjakan, siswa mulai berminat mengerjakan soal-soal latihan. Kemudian penulis memberikan soal evaluasi. Siswa mengerjakan soal evaluasi dengan semangat sesuai konsep yang telah mereka lakukan pada LKS-06. Setelah selesai jawaban mereka dikumpul. Kemudian penulis 
membahas bersama-sama terlihat siswa senang dengan jawaban mereka dan merasa bangga telah berhasil menjawab dengan benar, mereka saling bertanya-tanya kepada teman-temannya tentang hasil jawaban masing-masing.

Pada penutup penulis kembali mengingatkan siswa untuk membacamateri berikutnya. Dan meminta siswa masing-masing membawa kayu yang lurus dan panjangnya tidak ditentukan serta juga membawa tali. Selajutnya penulis memberikan tugas untuk mereka kerjakan dirumah. Pada pertemuan indikator ulet menghadapi kesulitan, indikator percaya diri, untuk indikator minat terhadap persoalan matematika dan indikator manfaat materi pelajaran matematika mulai ada peningkatan.

Pada penutup penulis meminta siswa mengisi angket dan menjelaskan bahwa tidak ada pengaruh angket dengan nilai mereka. Setelah semua selesai menjawab penulis meminta siswa belajar di rumah untuk menghadapi test 2 dari materi yang telah dipelajari. Pada pertemuan indikator ulet menghadapi kesulitan, indikator percaya diri, untuk indikator minat terhadap persoalan matematika dan indikator manfaat materi pelajaran matematika mulai ada peningkatan.

Penyajian dan Analisis Hasil penelitian

a) Hasil Analisis Data seluruh Indikator

Tabel 3. Skor Motivasi Siswa Terhadap Pelajaran Matematika Sebelum dan Sesudah Pembelajaran Model Pembelajaran ARIAS Dengan Laboratorium Mini

\begin{tabular}{cccc}
\hline No & \multicolumn{2}{c}{ Skor Angket Siswa } & Tanda dari $\left(\mathrm{X}_{2}-\mathrm{X}_{1}\right)$ \\
& Sebelum $\left(\mathrm{X}_{1}\right)$ & Sesudah $\left(\mathrm{X}_{2}\right)$ & \\
\hline 1 & 54 & 54 & + \\
2 & 55 & 55 & 0 \\
3 & 55 & 55 & + \\
4 & 56 & 61 & - \\
5 & 62 & 57 & \\
\hline
\end{tabular}


Model Pembelajaran ARIAS dengan Laboratorium Mini dalam Meningkatkan Motivasi Belajar Matematika Siswa Kelas X SMA, Endan Ratnawati

Lanjutan Tabel 3. Skor Motivasi Siswa Terhadap Pelajaran Matematika Sebelum dan Sesudah Pembelajaran Model Pembelajaran ARIAS Dengan Laboratorium Mini

\begin{tabular}{|c|c|c|c|}
\hline \multirow[t]{2}{*}{ No } & \multicolumn{2}{|c|}{ Skor Angket Siswa } & \multirow[t]{2}{*}{ Tanda dari $\left(\mathrm{X}_{2}-\mathrm{X}_{1}\right)$} \\
\hline & Sebelum $\left(\mathrm{X}_{1}\right)$ & $\operatorname{Sesudah}\left(\mathrm{X}_{2}\right)$ & \\
\hline 6 & 62 & 57 & - \\
\hline 7 & 55 & 55 & 0 \\
\hline 8 & 55 & 55 & 0 \\
\hline 9 & 56 & 61 & + \\
\hline 10 & 62 & 57 & - \\
\hline 11 & 57 & 60 & + \\
\hline 12 & 63 & 64 & + \\
\hline 13 & 61 & 62 & + \\
\hline 14 & 55 & 68 & + \\
\hline 15 & 63 & 73 & + \\
\hline 16 & 73 & 80 & + \\
\hline 17 & 69 & 63 & + \\
\hline 18 & 67 & 67 & 0 \\
\hline 19 & 63 & 65 & + \\
\hline 20 & 61 & 62 & + \\
\hline 21 & 57 & 65 & + \\
\hline 22 & 67 & 67 & 0 \\
\hline 23 & 60 & 59 & - \\
\hline 24 & 55 & 68 & + \\
\hline 25 & 63 & 73 & + \\
\hline 26 & 73 & 80 & + \\
\hline 27 & 69 & 63 & + \\
\hline 28 & 67 & 67 & 0 \\
\hline 29 & 55 & 55 & 0 \\
\hline
\end{tabular}


30

31

32
56

62

57
61

57

60
$+$

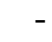

b) Analisis Data

Dari data yang tertera pada tabel 3. diatas tampak bahwa tanda (+) adalah sebanyak 18 tanda (-) sebanyak 3, tanda 0 sebanyak 6 maka di dapat:

$$
\begin{aligned}
& X=18 \\
& N=21
\end{aligned}
$$

Karena $X>1 / 2 \mathrm{~N}$ maka digunakan $\mathrm{X}-0,5$ (persamaan 3)

$$
\begin{aligned}
& Z=\frac{(X \pm 0,5)-\frac{1}{2} N}{\frac{1}{2} \sqrt{ } N} \\
& =\frac{(18-0,5)-\frac{1}{2} \cdot 21}{\frac{1}{2} \sqrt{2} 1} \\
& =\frac{(17,5-10,5)}{\frac{1}{2}(4,48)}=3,125
\end{aligned}
$$

Karena $\mathrm{Z}=0,4991$ maka dari tabel distribusi normal diperoleh $\mathrm{P}=0,0009$ dengan $\alpha=$ 0,01 .

Dari hasil analisis diatas dapat dinyatakan bahwa $\mathrm{P}<(\alpha=0,01)$ berarti hipotesis (Ho) ditolak, jadi Hi diterima pada taraf kepercayaan $99 \%$ berarti terdapat peningkatan motivasi siswa terhadap matematika sesudah pembelajaran dengan Model Pembelajaran ARIAS Dengan Laboratorium Mini dikelas X-2 SMA Negeri 1 Pasir Penyu Kabupaten Indragiri Hulu.

c) Hasil Analisis Data untuk setiap Indikator

Pengolahan data dapat dilakukan untuk setiap indikator. Data tersebut dapat dilihat pada tabel berikut: 
Tabel 4. Data Motivasi Belajar Matematika Siswa Untuk Setiap Indikator

\begin{tabular}{cccccc}
\hline Indikator & $\mathrm{Z}$ & $\mathrm{P}$ & $\square$ & $\mathrm{H}_{0}$ & Kesimpulan \\
\hline 1 & 0,4970 & 0,0030 & 0,01 & Ditolak & Meningkat \\
2 & 0.4982 & 0,0018 & 0,01 & Ditolak & Meningkat \\
3 & 0,4924 & 0.0076 & 0,01 & Ditolak & Meningkat \\
4 & 0,4970 & 0,0030 & 0,01 & Ditolak & Meningkat \\
5 & 0,4970 & 0,0030 & 0,01 & Ditolak & Meningkat \\
\hline
\end{tabular}

Berdasarkan fakta pada tabel 4. maka dapat dinyatakan bahwa:

1) Keuletan siswa dalam menghadapi kesulitan lebih baik setelah diterapkan model pembelajaran ARIAS dengan Laboratorium Mini.

2) Kepercayaan diri siswa lebih baik setelah diterapkan model pembelajaran ARIAS dengan Laboratorium Mini.

3) Jiwa bersaing dan kompetisi semakin baiksetelah diterapkan model pembelajaran ARIAS dengan Laboratorium Mini.

4) Minat siswa terhadap persoalan matematika lebih baik setelah diterapkan model pembelajaran ARIAS dengan Laboratorium Mini.

Keinginan belajar matematika bagi siswa lebih baik setelah diterapkan model pembelajaran ARIAS dengan Laboratorium Mini..

\section{SIMPULAN DAN SARAN}

Berdasarkan hasil analisis data angket motivasi, secara keseluruhan dapat disimpulkan bahwa terdapat peningkatan motivasi belajar matematika siswa setelah penerapan model pembelajaran ARIAS dengan Laboratorium Mini. Berdasarkan analisis data untuk setiap indikator juga terdapat peningkatan motivasi belajar matematika siswa setelah penerapan model pembelajaran ARIAS dengan Laboratorium Mini. Adapun indikator tersebut ulet menghadapi kesulitan, percaya diri, bersaing/kompetisi, minat terhadap persoalan matematika, dan keinginan untuk belajar matematika.

Selama penelitian berlangsung pada siklus pertama penulis banyak mengalami kesulitan antara lain: penulis mengalami kesulitan mengarahkan agar tidak ribut mengerjakan LKS; pengamat mengatakan bahwa penulis kurang keras suaranya dalam menjelaskan materi dan langkah-langkah pada LKS; dari penulis sendiri ada kekurangan pada LKS, dimana pada LKS penulis tidak ada memerintahkan kepada siswa membuat gambar bangun-bangun ruang sesuai keinginan siswa sendiri sehingga, contoh gambar pada LKS sia-sia saja yang mereka lakukan dalam mengerjakan soal evaluasi tidak sesuai dengan waktu yang penulis tentukan. Selain ada kekurangan juga ada kelebihan disini siswa terlihat senang dalam mengerjakan apa yang diperintahkan pada LKS dan siswa juga lebih aktif bertanya jika mengalami kesulitan. Dari lima indikator yang mulai nampak pada siklus pertama yaitu: indikator ulet menghadapi kesulitan dan percaya diri sedang indikator minat terhadap persoalan matematika dan keinginan belajar matematika belum ada peningkatan.

Selanjutnya untuk siklus kedua penulis berusaha memperbaiki kekurangan-kekurangan dan mempertahankan kelebihan. Semakin hari siswa terlihat menyelesaikan LKS dengan sungguhsungguh menujukan siswa mulai menghadapi kesulitan. Percaya diri siswa juga semakin meningkat, 
ini terihat disaat penulis meminta siswa membacakan kesimpulan dan dalam membahas soal evalusi. Siswa sering menanyakan soal latihan yang adapada buku paket ini menujukan siswa mulai berminat terhadap persoalan matematika. Keinginan belajar matematika juga terlihat disaat penulis mengemukakan dalam kehidupan sehari-hari yang relevan terhadap materi yang diperajari siswa juga ikut memberikan contoh-contoh yang ada hubungannya dengan materi pelajaran matematika.

Mengingat keterbatasan waktu dimana penelitian hanya dilaksanakn dalam enam kali pertemuan, pada dasarnya belum ideal. Hal ini disebabkan karena siswa sebagai objek penelitian baru pertama kali mengikuti pembelajaran sebagaimana ditetapkan. Selama tindakan, penulis tidak menemukan kejadian yang tak diduga selama proses pembelajaran berlangsung

Melalui tulisan ini penulis mengajukan beberapa saran yang berhubungan dengan penerapan Model Pembelajaran ARIAS dengan Laboratorium mini dalam pembelajaran matematika.

1. Kepada guru matematika SMA khususnya SMA Negeri I Pasir Penyu Kabupaten Indragiri Hulu agar dapat menjadikan Model Pembelajaran ARIAS dengan Laboratorium Mini sebagai salah satu alternatif pembelajaran di sekolah.

2. Hasil penelitian ini dapat dijadikan landasan berpijak bagi peneliti yang berninat mengembangkan hasil penelitian ini dalam ruang lingkup yang lebih besar.

3. Bagi peneliti lain untuk mencari informasi jangan dari guru saja tetapi siswa juga, sehingga data yang didapat akurat

\section{DAFTAR PUSTAKA}

Astuti, A. (2016). Pengaruh Model Pembelajaran Kooperatif Tipe Two Stay Two Stray (Tsts) Terhadap Hasil Belajar Matematika Siswa Kelas Vii Smp Negeri 2 Bangkinang Kota. Jurnal Cendekia : Jurnal Pendidikan Matematika, (2), 11-28. Retrieved From Http://Journal.Stkiptam.Ac.Id/Index.Php/Cendekia/Article/View/626

Asmiana, W, 2003, Perbedaan Rasa Percaya Diri antara Mahasiswa yang Aktifdengan Mahasiswa yang Tidak Aktif dalam Organisasi Kemahasiswaan di $U M M$, http://library.gunadarma.ac.id/print.php?id=jiptumm-gdl-sl-2003-windy-8II1-percaya-di.

Bahar, A, dan Maemunaty,T, 2003, Belajar dan Pembelajaran,UNR1, Pekanbaru.

Bell. F. H., 1978, Teaching and Learning Matematics, Wm. C. Brown Compony,Publishers Dubuque, Lowa.

Dimyati, dan Mudjiono., 2002, Belajar dan Pembelajaran, Rineka Cipta, Jakarta.

Hadi L, Satria, (2009), Total Motivation. Pro-you: Yogyakarta.

Hamalik, Oemar, (2006), Proses Belajar Mengajar. Bumi Aksara: Bandung.

Huduyo, H.. 1979, Pengembangan Kurikulum Matematika dan Pelaksanaan Didepan Kelas, Usaha Nasional, Surabaya.

Imran, A.,1996, Belajar dan Pembelajaran, Dunia Pustaka Jaya, Jakarta.

Maryunis, A., 1994, Pendekatan Laboratorium Dalam Proses Belajar MengajarMatematika, Makalah Di sampaikan Pada Seminar dan LokakaryaPengembangan Alat Peraga Matematika, Jurusan PendidikanMatematika Ilmu Pengetahuan Alam IKIP Padang, Padang.

Pusat Kurikulum., 2003, Kurikulum Berbasis Kompetensi, Depdikbud, Jakarta. 
Ruseffendi., 1988, Pengantar kepada Membantu Guru MengembangkanKompetensinya dalam Pengajaran Matematika untuk MeningkatkanCBSA, Tarsito, Bandung.

Ruseffendi, E. T., 1990, Pengajaran Matematika Modern Dan masa Kini, Tarsito,Bandung

Sadiq, F., 2004, Geometri (disamping pada Diklat Instruktur/PengembangMatematika SD Jenjang Lanjut Tanggal 6 s.d 19 Agustus 2004 di PPF Matematika,http://www.p3gmatyo.go.id/download/SD/Geometri.pdf

Saragih, S., 2002. Penerapan Metode Pembelajaran Kooperatif dengan Menggunakan Lab Mini untuk Meningkatkan Kemampuan Keruangan, Tesis tidak Diterbitkan, IKIP Surabaya, Surabaya.

Sardiman, A.M., 2001, Interaksi dan Motivasi Belaiar Mengaiar, PT. RajaGrafindo Persada, Jakarta.

Soejdana, W., 1986, Strategi Belajar Matematika, Universitas Terbuka,Depdikbud.

Sopah, D., 1998, Penerapan Model Pembelajaran ARIAS.http://www.dekdiknas.go.id/jumal/3I/pengembanan dan penggunaan mode.htm.

Siegel, S., 1990, Statistik Nonparametrik untuk llmu-Ilmu Sosial, Gramediapustaka utama, Jakarta.

Sardiman. 2010. Interaksi \& Motivasi Belajar Mengajar. Jakarta: Rajawali Pres.

Sudrajat, A, (2008), Teori-teori Motivasi. [Online].Tersedia: http://akhmadsudrajat.wordpress.com/2008/02/06/. [15 Maret 2011].

Sudrajat, A, (2008), Media Pembelajaran. [Online]. Tersedia: http://akhmadsudrajat.wordpress.com/2008/01/12. [15 Maret 2011].

Sukardi., 2003, Metedologi Penelitian Pendidikan Kompetensi dan Pratik, PT.Bumi Aksara, Jakarta.

Syaiful Djamarah, Bahri dan Aswan Zain. 2006. Strategi Belajar Mengajar. Jakarta: Rineka Cipta.

Wardani., 2000, Penelitian Tindakan Kelas, Universitas Terbuka, Jakarta.

Zen, M., Gani, J.,1980, Laboratorium Matematika dan Penerapannya dalamnBelajar Mengajar Matematika, Lembaga Tekhnologi Pengajaran FKIE,Padang.

Zen. M., 1990, Laboratorium Matematika, FPMIPA IKIP, Padang

Zulfah, Z. (2017). Analisis Kesalahan Peserta Didik Pada Materi Persamaan Linear Dua Variabel Di Kelas Viii Mts Negeri Sungai Tonang. Jurnal Cendekia : Jurnal Pendidikan Matematika, 1(1), 1-5. Retrieved From Http://Journal.Stkiptam.Ac.Id/Index.Php/Cendekia/Article/View/90

Zulfah, Z. (2017). Tahap Preliminary Research Pengembangan Lkpd Berbasis Pbl Untuk Materi Matematika Semester 1 Kelas Viii Smp. Jurnal Cendekia : Jurnal Pendidikan Matematika, $1(2)$,

$1-12$.

Retrieved From Http://Journal.Stkiptam.Ac.Id/Index.Php/Cendekia/Article/View/184 